Case Report

\title{
A Case of Chyloperitoneum Secondary to Follicular Lymphoma and a Review of Prognostic Implications
}

\author{
Megan Jagosky, Brice Taylor, and Stephanie Parks Taylor \\ Carolinas Medical Center, Medical Education Building, 5th floor, P.O. Box 32861, Charlotte, NC 28232-2861, USA \\ Correspondence should be addressed to Megan Jagosky; megan.jagosky@carolinashealthcare.org
}

Received 8 April 2016; Accepted 8 June 2016

Academic Editor: Marie-Christine Kyrtsonis

Copyright (C) 2016 Megan Jagosky et al. This is an open access article distributed under the Creative Commons Attribution License, which permits unrestricted use, distribution, and reproduction in any medium, provided the original work is properly cited.

\begin{abstract}
Chyloperitoneum, or chylous ascites, is a rare condition characterized by milky-appearing fluid with elevated triglyceride content and the presence of chylomicrons. Malignancy, specifically lymphoma, is reported to be the predominant cause in Western countries. Previously, the prognosis for patients with chyloperitoneum due to lymphoma has been reported as poor. We present a case of chyloperitoneum and chylothorax due to follicular lymphoma with excellent response to bendamustine and Rituxan. A review of the literature indicates that patients with chyloperitoneum associated with lymphoma generally have a favorable response to contemporary treatment regimens.
\end{abstract}

\section{Background}

Chyloperitoneum, also known as chylous ascites, is a rare condition characterized by milky-appearing lymph fluid in the abdominal cavity. It presents slowly with gradual, painless abdominal distension. The patient may experience weight gain and dyspnea as the fluid exerts pressure on the diaphragm. Paracentesis is necessary for diagnosis as it will reveal turbid, milky fluid that is distinguished by chylomicrons and an elevated triglyceride content $(>200 \mathrm{mg} / \mathrm{dL}$ ). Abdominal malignancies, specifically lymphoma, is reported to be the predominant cause in Western countries [1]. The most likely mechanism of fluid accumulation is impingement of the drainage system and possible direct invasion into the lymphatics.

In 1982, Press et al. reviewed the largest series of patients with chyloperitoneum due to lymphoma and found prognosis to be poor-only 2 of 13 patients experienced long-term survival (greater than three months) [2]. One would predict that survival has improved since then with the emergence of superior chemotherapy regimens. We present a case of chylous ascites and chylothorax due to follicular lymphoma and review the literature with specific focus on response to treatment.

\section{Case Description}

A 78-year-old woman presented to an outside facility with dyspnea and abdominal fullness. Physical examination revealed abdominal distension with a fluid wave and decreased breath sounds with dullness to percussion in the left hemithorax. Paracentesis and thoracentesis were both performed, revealing creamy opaque fluid with an elevated triglyceride content. Cytological examination of the peritoneal fluid showed chylomicrons. Prior to presentation to our institution, she underwent thoracentesis four times and paracentesis five times with rapid recurrence of symptoms.

On presentation to our institution, computed tomography (CT) scan of the abdomen and pelvis revealed para-aortic lymphadenopathy (Figure 1). A CT scan of the thorax showed a large left pleural effusion with scattered mediastinal lymph nodes, but they were not enlarged using the size criteria. A CT-guided lymph node biopsy of the para-aortic abdominal nodes revealed small lymphoid cell proliferation (Figure 2). Flow cytometry analysis of the sample lymph node biopsied demonstrated a monoclonal B-cell population positive for CD10, CD19, and CD20 and negative for CD3 and CD5. Ki67 , a protein marker for cell proliferation, was low within the neoplastic follicles (less than 10\%). 

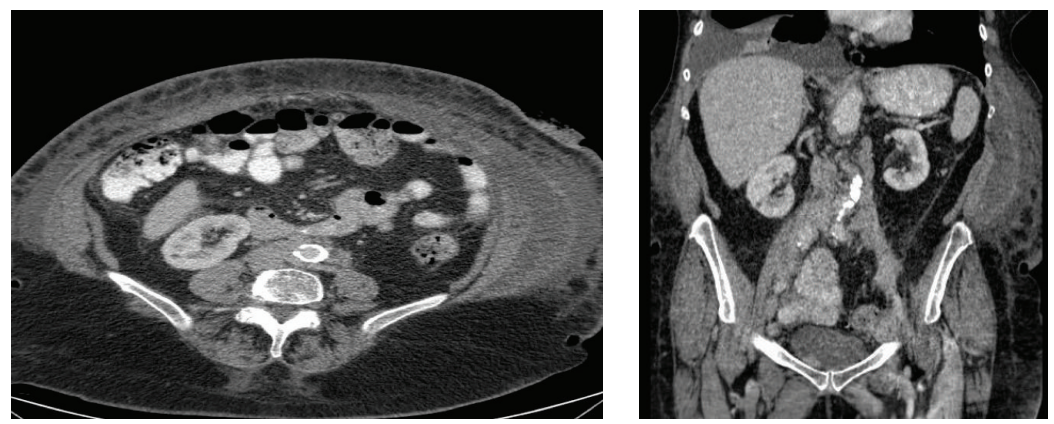

FIGURE 1: Coronal and transverse CT imaging of para-aortic lymphadenopathy.

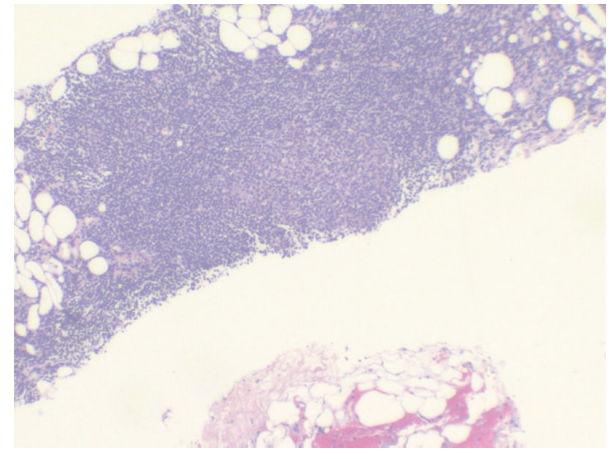

FIGURE 2: Lymph node biopsy pathology displaying small lymphoid cell proliferation.

Based on the histologic appearance and the low expression of Ki-67, the patient was diagnosed with low-grade follicular lymphoma. Due to the bulkiness of her disease with the multiple recurrent effusions, chemotherapy was pursued. Further staging workup with bone marrow biopsy and PET scan was deferred since it would not have changed management with the plan to pursue systemic therapy, regardless. She received four cycles of bendamustine and rituximab with complete resolution of both the ascites and pleural effusion. At one-year follow-up since complete resolution of her disease, she remained asymptomatic without reoccurrence of effusions; therefore, further chemotherapy was not pursued.

\section{Discussion}

Serous effusions are relatively common among malignant lymphomas. The most common effusion site is pleural, affecting $20-30 \%$ of NHL and Hodgkin lymphoma (HL), followed by pericardial and peritoneal [14]. Presence of an effusion historically portends a poor prognosis with higher risk for relapse after chemotherapy and decreased overall survival. While effusions in general are common in lymphoma, chylous effusions are exceedingly rare.

Targeting the underlying cause of chylous ascites is crucial to resolution, as in our patient who received follicular lymphoma-directed therapy. Treatment preferences for follicular lymphoma are varied since patients can live well for many years without treatment. Generally, stage I and stage II disease can be treated with watchful waiting or radiotherapy, whereas bulky stage II or stage III-IV can be treated with rituximab plus other biologic agents or chemotherapy, with or without radiotherapy [15]. Due to the rarity of follicular lymphoma-related chylous effusions, there are no guidelines for treatment. Conservative measures like dietary changes with protein rich, low-lipid foods can reduce chyle flow. Medium chain triglycerides are preferably consumed since they are directly absorbed and transported as free chain fatty acids and glycerol in the portal vein. Consumption of long chain fatty acids should be minimized since their metabolism leads to monoglycerides and free fatty acids that require transport by chylomicrons through the intestinal lymphatics [16]. Conservative measures are often ineffective in lymphoma; therefore, if lymphadenopathy is present, chemotherapy, or radiotherapy, or both can be pursued. In refractory cases, surgery can be utilized to ligate the thoracic duct or generate a pleuroperitoneal shunt [17].

To evaluate the current state of chyloperitoneum prognosis and treatment secondary to lymphoma, a search of the MED-LINE database was performed using the search terms "chylous ascites" or "chyloperitoneum" and "lymphoma". Fourteen cases from 10 unique publications were found that described chylous ascites secondary to lymphoma [3-13] (Table 1). In addition to our patient, six cases had both chylous ascites and chylous pleural effusion, with two cases also having chylopericardium. As in our case, most were associated with low-grade lymphomas and had excellent response to a variety of different chemotherapy regimens. Of the 14 patients, three had HL and 11 had NHL. Of the NHL cases, four had diffuse large B-cell lymphoma (DLBCL), two had follicular lymphoma, two had small-cleaved cell (unspecified), one had Burkitt's lymphoma, one had T-cell lymphoma, and one was unspecified. The two patients with the more aggressive subtypes (T-cell and Burkitt's lymphoma) died from their disease.

Our review of the contemporary literature suggests that the advent of superior chemotherapy regimens has led to marked improvement in survival and resolution of symptoms in most patients. Prior to the development of these regimens, lymphoma-related chylous effusions carried a dismal prognosis with greater than $90 \%$ of patients dying within three months of diagnosis before 1982 [2]. In the majority of 
TABLE 1: Chyloperitoneum associated with lymphoma.

\begin{tabular}{|c|c|c|c|c|c|c|}
\hline Case number & Author/year & Age/sex & Site & Diagnosis & Treatment & Outcome \\
\hline 1 & Current case & $78 / \mathrm{F}$ & $\begin{array}{l}\text { Peritoneal, } \\
\text { pleural, }\end{array}$ & Follicular lymphoma & $\begin{array}{c}\text { Bendamustine }+ \\
\text { rituximab }\end{array}$ & Resolution \\
\hline 2 & Arasawa, 2014 [3] & $74 / \mathrm{M}$ & Peritoneal & DLBCL & R-CHOP & Resolution \\
\hline 3 & Jiang, 2013 [4] & $28 / \mathrm{M}$ & $\begin{array}{l}\text { Peritoneal, } \\
\text { pleural }\end{array}$ & $\begin{array}{l}\text { Non-Hodgkin } \\
\text { Lymphoma }\end{array}$ & $\begin{array}{l}\text { DOLP + } \\
\text { HDAra-C }\end{array}$ & Resolution \\
\hline 4 & $\begin{array}{c}\text { Yamamoto, } 2013 \\
{[5]}\end{array}$ & $87 / \mathrm{M}$ & Peritoneal & DLBCL & R-CHOP & Resolution \\
\hline 5 & $\begin{array}{c}\text { Etonyeaku, } 2012 \\
{[6]}\end{array}$ & $18 / \mathrm{F}$ & $\begin{array}{l}\text { Peritoneal, } \\
\text { pleural }\end{array}$ & Burkitt's lymphoma & MEV & $\begin{array}{c}\text { Died due to treatment } \\
\text { effects }\end{array}$ \\
\hline 6 & Kashyap, 2011 [7] & $21 / \mathrm{F}$ & $\begin{array}{l}\text { Peritoneal, } \\
\text { pleural, } \\
\text { pericardial }\end{array}$ & DLBCL & R-CHOP & Resolution \\
\hline 7 & $\begin{array}{c}\text { Ionnidou- } \\
\text { Papagiannaki } 2009 \\
\text { [8] }\end{array}$ & $38 / \mathrm{M}$ & $\begin{array}{l}\text { Peritoneal, } \\
\text { pleural, } \\
\text { pericardial }\end{array}$ & T-cell lymphoma & CHOEP & $\begin{array}{l}\text { Died due to GI } \\
\text { bleeding }\end{array}$ \\
\hline 8 & Gonen, 2007 [9] & $53 / \mathrm{M}$ & Peritoneal & Hodgkin lymphoma & ABVD & $\begin{array}{l}\text { Regression after two } \\
\text { cycles chemotherapy }\end{array}$ \\
\hline 9 & Ward, 2008 [10] & $\begin{array}{l}\text { Middle } \\
\text { age/F }\end{array}$ & Peritoneal & Follicular lymphoma & $\begin{array}{l}\text { Chemotherapy } \\
\text { unspecified }\end{array}$ & Resolution \\
\hline 10 & $\begin{array}{c}\text { Bachmeyer, } 2004 \\
{[11]}\end{array}$ & $71 / \mathrm{M}$ & Peritoneal & $\begin{array}{l}\text { Follicular } \\
\text { lymphoma }\end{array}$ & $\begin{array}{c}\text { CHVP + interferon } \\
\text { alpha }\end{array}$ & $50 \%$ reduction \\
\hline 11 & $\begin{array}{l}\text { Oosterbosch, } 1995 \\
{[12]}\end{array}$ & $68 / \mathrm{F}$ & $\begin{array}{l}\text { Peritoneal, } \\
\text { pleural }\end{array}$ & DLBCL & CVP & Regression \\
\hline 12 & Hufford, 1988 [13] & $49 / \mathrm{F}$ & Peritoneal & $\begin{array}{c}\text { Mixed cellularity } \\
\text { (Hodgkin lymphoma) }\end{array}$ & $\begin{array}{l}\text { CVP, doxorubicin } \\
\text { followed by CHOP }\end{array}$ & Resolution \\
\hline 13 & Hufford. 1988 [13] & $67 / \mathrm{F}$ & Peritoneal & $\begin{array}{l}\text { Small cleaved cell } \\
\text { (NHL) }\end{array}$ & CVP & $\begin{array}{l}\text { No response to } \\
\text { chemotherapy, } \\
\text { resolution after } \\
\text { diuretics }\end{array}$ \\
\hline 14 & Hufford, 1988 [13] & $58 / \mathrm{M}$ & Peritoneal & Hodgkin lymphoma & MOPP & Resolution \\
\hline 15 & Hufford, 1988 [13] & $60 / \mathrm{M}$ & Peritoneal & $\begin{array}{c}\text { Small cleaved cell } \\
\text { (NHL) }\end{array}$ & $\mathrm{CHOMP}+$ bleomycin & Resolution \\
\hline
\end{tabular}

R-CHOP: rituximab, cyclophosphamide, doxorubicin, vincristine, and prednisone; CVP: cyclophosphamide, vincristine, and prednisolone; CHOMP: cyclophosphamide, doxorubicin, vincristine, and prednisone + bleomycin; MOPP: Mustargen, Oncovin, procarbazine, and prednisone; CHVP: cyclophosphamide, doxorubicin, etoposide, and prednisolone; ABVD: doxorubicin, bleomycin, vinblastine, and dacarbazine; CHOEP: cyclophosphamide, hydroxydaunorubicin, Oncovin, etoposide, and prednisone; DOLP: daunorubicin, vincristine, L-asparaginase, and prednisone; HDAra-C: high dose cytarabine; MEV: methotrexate, cyclophosphamide, and vincristine.

cases published since that time, chemotherapeutic regimens directed to specific lymphoma subtypes allowed for a significant beneficial effect. Twelve of the fourteen cases noted here had significant regression of disease and complete or near complete resolution of effusions. Long-term follow-up was only described in three cases with one patient surviving until 18 months [8] and another two surviving, symptom free, at least until the one-year and eight-month follow-up, respectively $[10,13]$. Our patient is, to our knowledge, the first published case treated with bendamustine and rituximab. As in the other cases reviewed, her outcome was a positive one and, because of current therapies, she continued to thrive beyond one year after diagnosis.

\section{Consent}

Written informed consent was obtained from the patient for publication of this case report and any accompanying images.

\section{Competing Interests}

The authors declare that they have no competing interests.

\section{Authors' Contributions}

Brice Taylor conceived of the study and drafted the paper. Stephanie Parks Taylor acquired patient information, participated in the concept of the report, and helped to draft the paper. Megan Jagosky helped with the literature review and correspondence. All authors read and approved the final paper.

\section{References}

[1] T. Almakdisi, S. Massoud, and G. Makdisi, "Lymphomas and chylous ascites: review of the literature," The Oncologist, vol. 10, no. 8, pp. 632-635, 2005. 
[2] O. W. Press, N. O. Press, and S. D. Kaufman, "Evaluation and management of chylous ascites," Annals of Internal Medicine, vol. 96, no. 3, pp. 358-364, 1982.

[3] S. Arasawa, H. Nakase, and N. Minami, "Gastroenterology: mesenteric lymphoma with chylous ascites," Journal of Gastroenterology and Hepatology, vol. 29, no. 8, p. 1570, 2014.

[4] Y. Jiang, W. Xie, K. Hu, J. Sun, X. Zhu, and H. Huang, "An aggressive form of non-Hodgkin's lymphoma with pleural and abdominal chylous effusions: a case report and review of the literature," Oncology Letters, vol. 6, no. 4, pp. 1120-1122, 2013.

[5] Y. Yamamoto, S. Kumei, T. Ogura, Y. Onishi, M. Maeda, and Y. Matsuno, "A case of primary gastric malignant lymphoma with chylous ascites," Journal of Japanese Society of Gastroenterology, vol. 110, no. 10, pp. 1790-1796, 2013.

[6] A. C. Etonyeaku, O. O. Akinsanya, O. Ariyibi, and A. J. Aiyeyemi, "Chylothorax from bilateral primary Burkitt's lymphoma of the ovaries: a case report," Case Reports in Obstetrics and Gynecology, vol. 2012, Article ID 635121, 3 pages, 2012.

[7] A. Kashyap, V. Mahajan, J. Whig, and S. Gupta, "Bilateral chylothorax, chylopericardium and chylous ascitis," Lung India, vol. 28, no. 2, pp. 133-135, 2011.

[8] E. Ionnidou-Papagiannaki, M. Diamantidis, I. Livanis et al., "Fatal chylous ascites, pericarditis and extensive venous thrombosis, due to an aggressive T cell non-hodgkin lymphoma," Annals of Hematology, vol. 88, no. 4, pp. 371-373, 2009.

[9] C. Gonen, M. Akarsu, D. Solmaz et al., "Hodgkin's disease presenting with chylous ascites and cavernous transformation of the portal vein," Digestive Diseases and Sciences, vol. 52, no. 12, pp. 3511-3514, 2007.

[10] R. M. Ward and C. R. Rardin, "Symptomatic enterocele: an unusual presentation of chylous ascites and lymphoma," Obstetrics and Gynecology, vol. 111, no. 2, pp. 553-555, 2008.

[11] C. Bachmeyer, M. A. Henni, A.-S. Blanc, B. Langman, F. Kazerouni, and J.-F. Cadranel, "Chylous ascitis revealing a nonHodgkin lymphoma," La Presse Médicale, vol. 33, no. 3, pp. 167$169,2004$.

[12] L. Oosterbosch, A. Leloup, P. Verstraeten, and P. Jordens, "Chylothorax and chylous ascites due to malignant lymphoma," Acta Clinica Belgica, vol. 50, no. 1, pp. 20-24, 1995.

[13] S. Hufford and E. Hu, "Lymphoma and chylous ascites." Western Journal of Medicine, vol. 148, no. 5, pp. 581-583, 1988.

[14] D. K. Das, "Serous effusions in malignant lymphomas: a review," Diagnostic Cytopathology, vol. 34, no. 5, pp. 335-347, 2006.

[15] S. Luminari, M. Bellei, I. Biasoli, and M. Federico, "Follicular lymphoma-treatment and prognostic factors," Revista Brasileira de Hematologia e Hemoterapia, vol. 34, no. 1, pp. 5459, 2012.

[16] C. K. Baban, M. Murphy, C. O’Sulleabháin, and D. O'Hanlon, "Chylous ascites as a consequence of idiopathic pancreatitis," BMJ Case Reports, 2014.

[17] J. Evans, M. F. Clark, L. Mincher, and V. A. Varney, "Chylous effusions complicating lymphoma: a serious event with octreotide as a treatment option," Hematological Oncology, vol. 21, no. 2, pp. 77-81, 2003. 


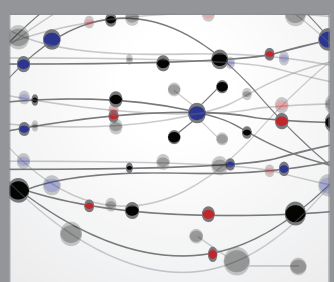

The Scientific World Journal
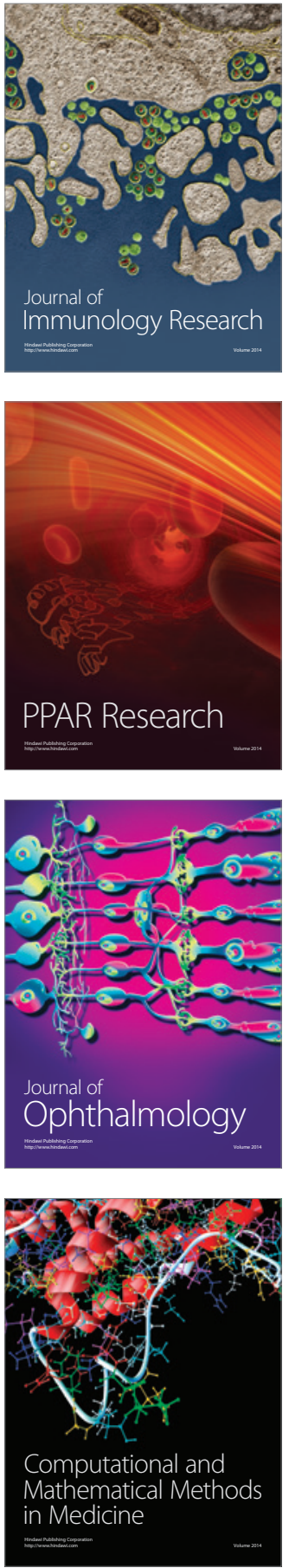

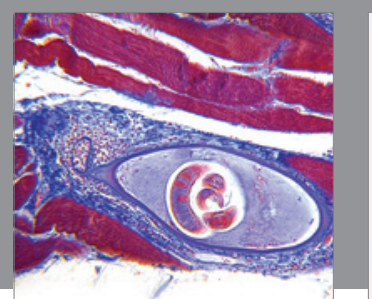

Gastroenterology Research and Practice

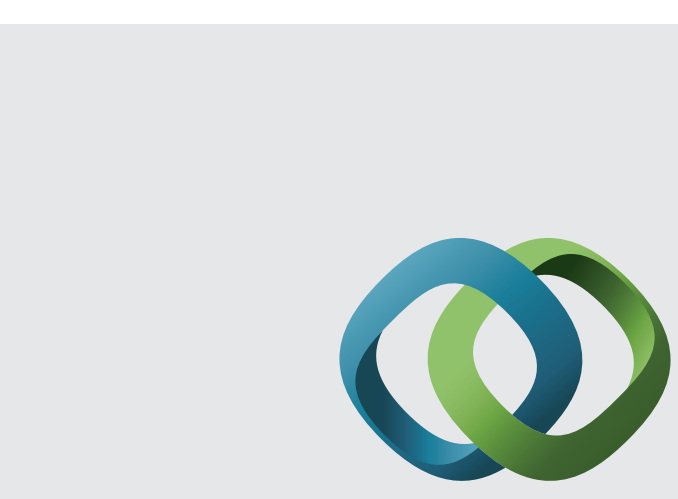

\section{Hindawi}

Submit your manuscripts at

http://www.hindawi.com
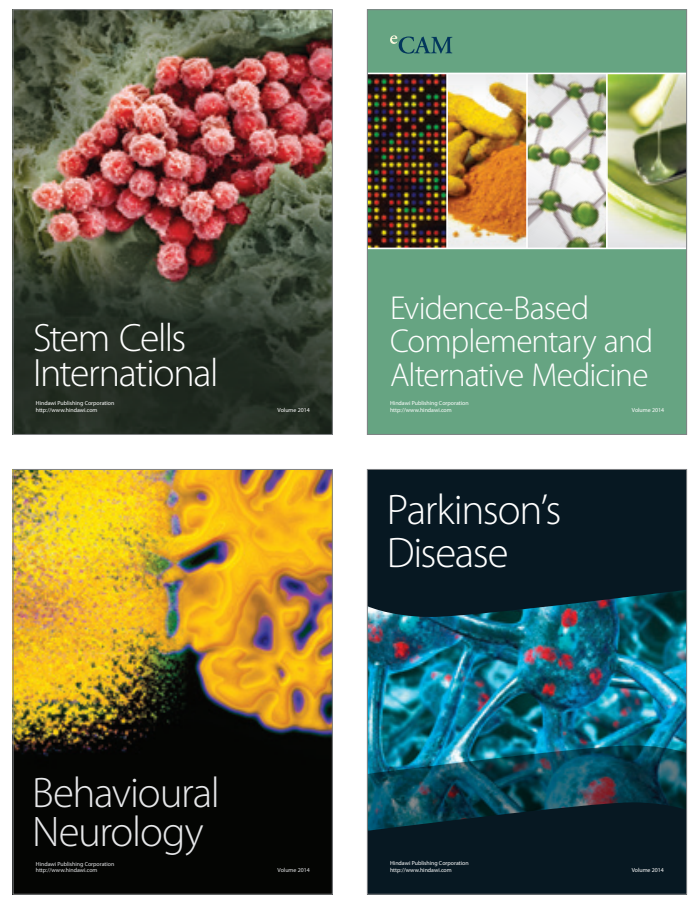
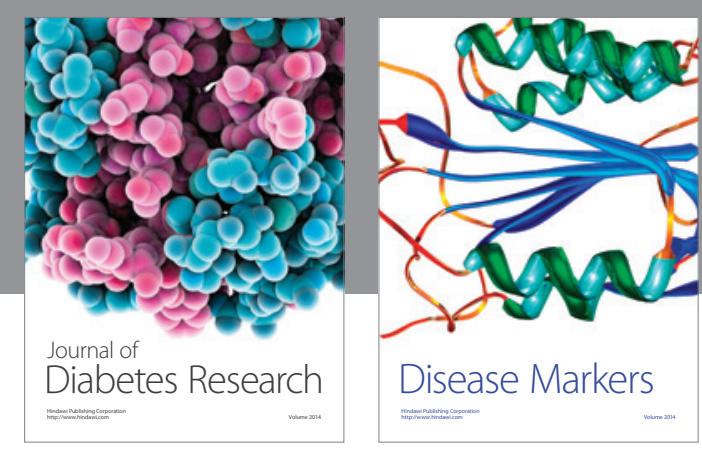

Disease Markers
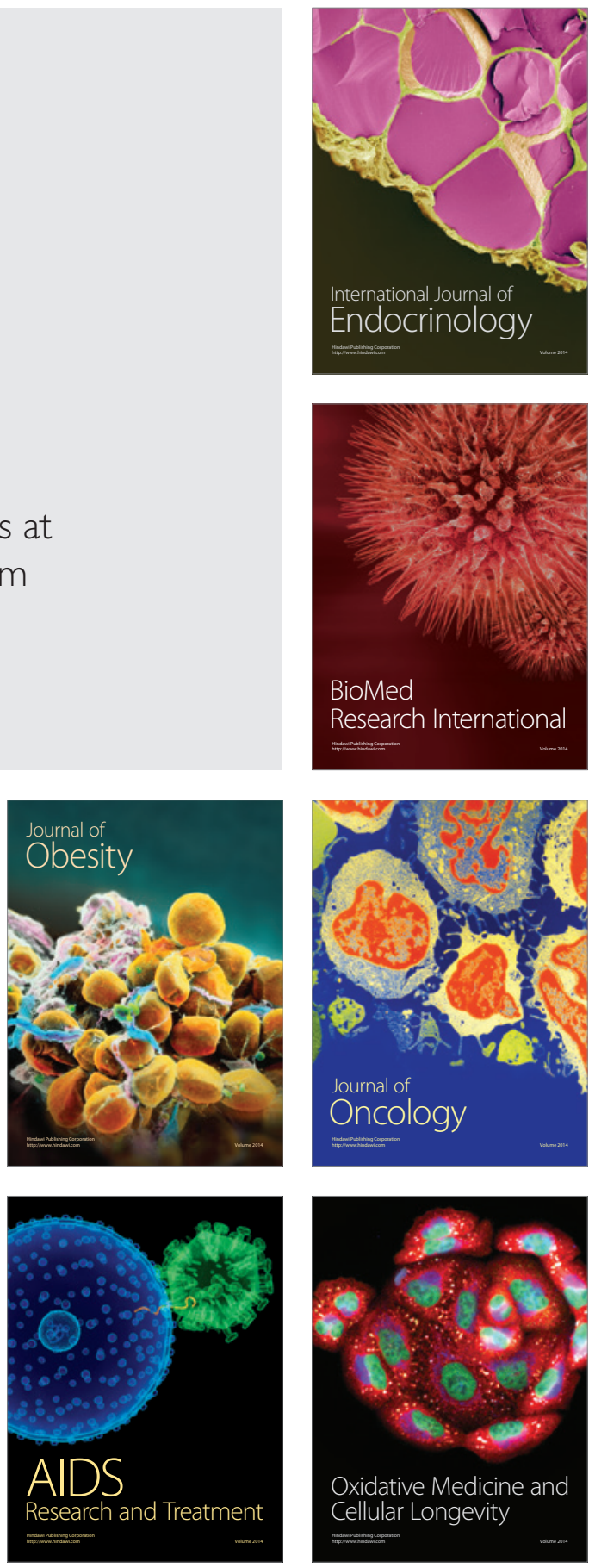